\title{
MONSOON SEASONS WATER QUALITY STATUS OF GROUND WATER SYSTEM IN TAKHATPUR, BILASPUR DISTRICT, CHHATTISGARH, INDIA
}

\author{
Rakesh Kumar Yadav ${ }^{1}$ and M.R. Augur ${ }^{2}$ \\ ${ }^{1}$ Departmentof Chemistry, Dr. C. V. Raman University, Kota, \\ Bilaspur-495113, (Chhattisgarh) India \\ ${ }^{2}$ Department of Chemistry, Govt. Agrassen P.G. College, Bilha, \\ Bilaspur, 495222, (Chhattisgarh) India \\ *E-mail : rakeshyadav96@gmail.com
}

\begin{abstract}
People on the globe are under tremendous threat due to an undesired change in the physical, chemical and biological characteristics of water. Due to increased human population, use of fertilizers and man-made activity water is highly polluted with different harmful contaminants. Natural water contaminants due to weathering of rocks and leaching of soil. It necessary that the quality of drinking water should be checked of the regular time interval, because due to use of contaminated drinking water. Human population suffers from varied of waterborne disease. The availability of good quality water is an indispensable feature for preventing disease and improving quality of life. it is to know details about different physic-chemical such as Temperature, pH, EC, Turbidity, TS, TSS, TDS, TH, Alkalinity, DO, BOD, COD, Chloride, Sulphate, Phosphate, Fluoride, Nitrate, Na, K, Ca, Mg, Fe, Zn, Mn, Pb used for testing of water quality.
\end{abstract}

Key Words: Monsoon Season, Ground Water, Trace Metals, Takhatpur Region.

(C) RASĀYAN. All rights reserved

\section{INTRODUCTION}

Ground water includes all water found beneath the earth's surface and part of the earth's natural hydrological cycle $^{1-3}$. It is the body of water derived primarily from percolation and contained in pore spaces of a pore space of soil, gravels, cracks and permeable rock like sandstone, limestone and other rocks. 30\% of liquid fresh water is stored underground in aquifers within a few kilometers of the earth's surface almost everywhere, beneath hills, mountains, plains and deserts ${ }^{4-6}$. Ground water is ultimate and most suitable freshwater resource for human consumption in both urban as well as rural areas. Sources of groundwater are gravity spring, surface spring, artesian spring, shallow well, jack well, infiltration gallery, infiltration well, deep well and tube wells. The quality of groundwater depends upon several factors including climate, soil, characteristics of geological data, the manner of circulation of ground water through the rock types and its chemical reaction with minerals, the topography of the area, saline water intrusion in the coastal area and metal pollution through weathering and anthropogenic activities on the ground ${ }^{7}$. Assessment of ground water quality is a complex problem. India is a vast country having diversified geological, climate logical and topographical set-up giving rise to divergent groundwater situation $^{8-9}$. Heavy metals tend to precipitate phosphate biocompounds and catalyze their decomposition. These are also identified as deleterious to human health. Heavy metals bind to cell membrane affecting transport processes through the cell wall. They attack sulphur bonds, thus immobilizing the enzymatic system. Other vulnerable sites are protein, carboxylic acid and amino groups ${ }^{10}$. The essential micronutrients for plants are $\mathrm{B}, \mathrm{Na}, \mathrm{Cu}, \mathrm{Fe}, \mathrm{Mn}, \mathrm{Zn}, \mathrm{V}, \mathrm{Mo}$, these elements are required at trace levels and, if present at higher amount exert a toxic effect. Most of these element act as components of essential enzymes. Elements such as $\mathrm{Mn}, \mathrm{Fe}, \mathrm{Zn}, \mathrm{V}$, and $\mathrm{Cl}$ are likely to take part in photosynthesis. Several other elements like $\mathrm{Cr}, \mathrm{Ni}, \mathrm{Fe}, \mathrm{Mn}$ have been found to stimulate plant growth and regarded as potential micronutrients. Out of 35 elements, 16 elements promote metabolic activity in plants. 


\section{EXPERIMENTAL}

Sampling spots had been selected as the background of the degree of pollution around the Takhatpur urban and rural area. The locations of sampling spots are given in Table-1, named from TG1 to TG8.

\section{Method for Sample Collection}

Groundwater samples were collected at fixed time viz. 1st date of every month Between 9:00 am to 4:00 $\mathrm{pm}$ in stopper polyethylene bottles of 2L capacity, for physicochemical analysis while glass bottles were used for heavy metals. Before sampling containers were washed in order of $6 \mathrm{~N} \mathrm{HNO}_{3}$, Tap water, Bore wells water and finally with water samples respectively.

\section{Preservation Technique}

For physicochemical analysis, water samples were preserved by keeping in Refrigerator at $4{ }^{\circ} \mathrm{C}$ and adding 3-4 drops of conc. $\mathrm{HNO}_{3}$ to minimize the $\mathrm{pH}$ below 2 to avoid precipitation or degradation of dissolved and suspended metallic elements.

\section{Detection Method}

Temperature-Electrometric, pH-Electrometric, Electrical Conductivity(EC)-Electrometric, TurbidityTurbidity metric, Total Dissolved Solid(TDS)-Gravimetric, Total Solids (TS)-Gravimetric, Total Suspended Solid(TSS)-Mathematical, Total Hardness(TH)-EDTA Titrimetric, Alkalinity-Titrimetric, Dissolved Oxygen(DO)-Electrometric, Biological Oxygen Demand(BOD)-Incubation method, Chemical Oxygen Demand(COD)-Digestion method, Chloride(CL $\left.\mathrm{CL}^{-}\right)$-Argentometric method, Sulphate $\left(\mathrm{SO}_{4}{ }^{2^{-}}\right)$Spectrophotometric Method, Phosphate $\left(\mathrm{PO}_{4}{ }^{3^{-}}\right)-\mathrm{SnCl}_{2}$ method, Fluoride( $\left.\mathrm{F}^{-}\right)$-SPANDS method, Nitrate $\left(\mathrm{NO}_{3}{ }^{-}\right)$Phenol Disulphonic Acid method, Sodium(Na)Flame emission Photometric method, Potassium(K)Flame photometric method, Calcium-EDTA Titrimetric method, Magnesium-EDTA Titrimetric method, Iron(Fe)-1,10 phenanthroline method, Zinc(Zn)-Zincon method, Manganese (Mn)-Per sulphate method, Lead $(\mathrm{Pb})$ - Dithizone method.

Table-1: Name of Sampling Spot and Code

\begin{tabular}{c|c|c}
\hline S. No. & Name of Sampling Spot & Code \\
\hline 1 & Takhatpur Town & TG1 \\
\hline 2 & Khamariya & TG2 \\
\hline 3 & Daukapa & TG3 \\
\hline 4 & Belpan & TG4 \\
\hline 5 & Khapari & TG5 \\
\hline 6 & Nigarbandh & TG6 \\
\hline 7 & Daija-Bija & TG7 \\
\hline 8 & Rajakapa & TG8 \\
\hline
\end{tabular}

\section{RESULTS AND DISCUSSION}

\section{Temperature}

The minimum value of temperature was noted on TG6 $\left(19.98^{\circ} \mathrm{C}\right)$ in the month of September2014 and the maximum value was noted on TG6 $\left(23.59^{\circ} \mathrm{C}\right)$ in the month of July'2014, while the standard value of BIS and WHO is $27-28^{\circ} \mathrm{C}$.

\section{pH}

The minimum value of $\mathrm{pH}$ was observed on TG7 (6.46) in the month of September2014 and the maximum value of $\mathrm{pH}$ was observed on TG1 and TG5 (7.98) in the month of September2015 and October2015, while the standard value of BIS and WHO is 6.5-8.5 respectively.

\section{Electrical Conductivity}

The minimum value of electrical conductivity was analyzed on TG4 $(718.97 \mu \mathrm{s} / \mathrm{cm})$ in the month of September 2014 and the maximum value was analyzed on TG5 $(748.98 \mu \mathrm{s} / \mathrm{cm})$ in the month of July'2014, while the standard value of BIS and WHO is 750-2250 and 400-2000 respectively. 


\section{Turbidity}

The minimum value of turbidity was noted on TG3 and TG2,TG2 and TG3 (4.1NTU) in the month of September-October 2014, September and October 2015 and maximum value of turbidity was noted on TG6 (5.08NTU) in the month of July'2014, while the standard value of BIS and WHO is 5.0-8.0 and 5.010.0 respectively.

\section{Total Solids}

The minimum value of TS was calculated on TG8 $(506.98 \mathrm{mg} / \mathrm{L})$ in the month of October2015 and the maximum value of TS was calculated on TG1 $(518.96 \mathrm{mg} / \mathrm{L})$ in the month of July'2014, while the standard value of BIS and WHO is 520-2050 and 500-1500 mg/L respectively.

\section{Total Dissolved Solids}

The minimum value of TDS was recorded on TG1 $(492.19 \mathrm{mg} / \mathrm{L})$ in the month of September2014 and the maximum value of TDS was recorded on TG1 $(500.64 \mathrm{mg} / \mathrm{L})$ in the month of July'2014, while the standard value of BIS and WHO is 500-2000 and 500-1500 mg/L respectively.

\section{Total Suspended Solids}

The minimum value of TSS was examined on TG7 $(10.64 \mathrm{mg} / \mathrm{L})$ in the month of October2015 and the maximum value of TSS was examined on TG1 $(18.73 \mathrm{mg} / \mathrm{L})$ in the month of August2014, while the standard value of BIS and WHO is $20-50$ and $100-600 \mathrm{mg} / \mathrm{L}$ respectively.

Table-2: Range of TG1- TG4 in Monsoon (July 2014-October2015)

\begin{tabular}{l|c|c|c|c}
\hline \multirow{2}{*}{ Parameters } & TG1 & TG2 & TG3 & TG4 \\
\cline { 2 - 5 } & Range & Range & Range & Range \\
\hline Temperature & $20.15-22.28$ & $20.22-22.57$ & $20.11-22.68$ & $21.42-22.24$ \\
\hline $\mathrm{pH}$ & $7.14-7.98$ & $6.54-7.59$ & $7.23-7.96$ & $6.85-7.87$ \\
\hline EC & $738.97-746.98$ & $739.56-748.98$ & $738.73-748.98$ & $718.97-734.89$ \\
\hline Turbidity & $4.2-5.5$ & $4.1-5.4$ & $4.1-5.6$ & $4.7-5.9$ \\
\hline TS & $509.37-518.96$ & $512.87-517.84$ & $509.76-516.64$ & $509.98-516.28$ \\
\hline TDS & $492.19-500.73$ & $498.54-500.56$ & $493.14-498.21$ & $495.64-499.41$ \\
\hline TSS & $16.38-18.73$ & $14.08-17.32$ & $14.46-18.43$ & $13.84-18.67$ \\
\hline TH & $201-212$ & $201-212$ & $203-212$ & $203-213$ \\
\hline Alkalinity & $203-218$ & $210-232$ & $205-215$ & $205-215$ \\
\hline DO & $5.2-5.7$ & $5.01-5.4$ & $5.03-5.2$ & $5.06-6.5$ \\
\hline BOD & $0.5-1$ & $0.6-0.9$ & $0.5-0.9$ & $0.7-0.9$ \\
\hline COD & $1-1.8$ & $0.9-1.4$ & $0.9-1.5$ & $1-1.3$ \\
\hline Chloride $\left(\mathrm{Cl}^{-}\right)$ & $154.21-175.25$ & $152.65-162.14$ & $142.3-157.25$ & $145.32-156.23$ \\
\hline Sulphate $\left(\mathrm{SO}_{4}{ }^{-}\right)$ & $116-135$ & $110-117$ & $106-116$ & $104-125$ \\
\hline Phosphate $\left(\mathrm{PO}_{4}{ }^{3-}\right)$ & BDL & BDL & BDL & BDL \\
\hline Fluoride $\left(\mathrm{F}^{-}\right)$ & $0.3-0.93$ & $0.3-0.7$ & $0.4-0.9$ & $0.53-0.94$ \\
\hline Nitrate $\left(\mathrm{NO}_{3}{ }^{-}\right)$ & $25.45-38.32$ & $34.65-44.76$ & $30.43-42.12$ & $35.21-44.29$ \\
\hline Sodium $\left(\mathrm{Na}^{-}\right)$ & $69-74$ & $32-55$ & $32-55$ & $54-67$ \\
\hline Potassium $\left(\mathrm{K}^{-}\right)$ & $7.22-9.45$ & $8.32-8.47$ & $7.65-9.34$ & $9.12-9.74$ \\
\hline Calcium & $45-65$ & $45-62$ & $45-52$ & $44-50$ \\
\hline Magnesium & $11-18$ & $18-23$ & $19-22$ & $21-28$ \\
\hline
\end{tabular}


RASĀYAN J. Chem.

Vol. 11 | No. 2 |537 - 543 | April - June | 2018

\begin{tabular}{l|c|c|c|c} 
Iron $(\mathrm{Fe})$ & $0.11-0.19$ & $0.13-0.23$ & $0.16-0.29$ & $0.16-0.29$ \\
\hline Zinc $(\mathrm{Zn})$ & BDL & BDL & BDL & BDL \\
\hline Manganese $(\mathrm{Mn})$ & BDL & BDL & BDL & BDL \\
\hline Lead $(\mathrm{Pb})$ & BDL & BDL & BDL & BDL \\
\hline
\end{tabular}

\section{Total Hardness}

The minimum value of TH was founded on TG1 and TG2 (201.00 mg/L) in the month of July'2014 and August2014 and maximum value of TH was founded on TG4 and TG8 $(213.00 \mathrm{mg} / \mathrm{L})$ in the month of September2014, while the standard value of BIS and WHO is 300-600 and 100-500 mg/L respectively.

\section{Alkalinity}

The minimum value of alkalinity was recorded on TG5 and TG6 $(201.00 \mathrm{mg} / \mathrm{L})$ in the month of July'2014 andOctober2015 and maximum value of alkalinity was recorded on TG2 $(216.00 \mathrm{mg} / \mathrm{L})$ in the month of September2015, while standard value of BIS and WHO is 300-600 and 200-600 mg/L respectively.

\section{Dissolved Oxygen}

The minimum value of DO was noted on TG2 $(5.01 \mathrm{mg} / \mathrm{L})$ in the month of September and October2014 and the maximum value of DO was noted on TG4 $(6.5 \mathrm{mg} / \mathrm{L})$ in the month of September and October2015, while the standard value of BIS and WHO is 5.0 and $5.0-6.0 \mathrm{mg} / \mathrm{L}$ respectively.

\section{Biological Oxygen Demand}

The minimum value of BOD was calculated on TG1 $(0.5 \mathrm{mg} / \mathrm{L})$ in the month of September 2014 and July'2015 and maximum value of BOD was calculated on TG1 $(1.0 \mathrm{mg} / \mathrm{L})$ in the month of October2014, while standard value of BIS and WHO is 5.0 and $5.0 \mathrm{mg} / \mathrm{L}$ respectively.

Table-3: Range of TG5- TG8 in Monsoon (July 2014-October2015)

\begin{tabular}{c|c|c|c|c}
\hline \multirow{2}{*}{ Parameters } & TG5 & TG6 & TG7 & TG8 \\
\cline { 2 - 5 } & Range & Range & Range & Range \\
\hline Temperature & $20.25-23.25$ & $19.98-23.59$ & $20.13-21.54$ & $21.42-22.24$ \\
\hline $\mathrm{pH}$ & $7.19-7.98$ & $6.57-6.94$ & $6.46-6.88$ & $6.86-7.87$ \\
\hline EC & $738.73-748.98$ & $728.98-737.92$ & $728.98-737.92$ & $718.97-734.89$ \\
\hline Turbidity & $4.6-5.3$ & $4.1-5.8$ & $4.3-5.3$ & $4.2-5.1$ \\
\hline TS & $514.87-518.08$ & $513.18-516.46$ & $508.69-514.99$ & $506.98-514.87$ \\
\hline TDS & $498.37-500.4$ & $499.12-501.6$ & $497.55-501.52$ & $494.51-499.24$ \\
\hline TSS & $14.47-18.17$ & $12.86-16.81$ & $10.64-16.32$ & $12.46-16.43$ \\
\hline TH & $205-212$ & $201-212$ & $203-212$ & $203-213$ \\
\hline Alkalinity & $201-215$ & $201-232$ & $205-215$ & $202-215$ \\
\hline DO & $5.4-5.4$ & $5.07-5.5$ & $5.4-6.8$ & $5.06-5.7$ \\
\hline BOD & $0.7-1$ & $0.7-1$ & $0.7-1.1$ & $0.7-1$ \\
\hline COD & $1.1-1.8$ & $1.1-1.8$ & $1-1.5$ & $1-1.5$ \\
\hline Chloride $\left(\mathrm{Cl}^{-}\right)$ & $140.65-148.45$ & $140.65-146.77$ & $140.65-148.02$ & $140.65-153.47$ \\
\hline Sulphate $\left(\mathrm{SO}_{4}{ }^{2-}\right)$ & $114-135$ & $265-285$ & $106-116$ & $104-125$ \\
\hline Phosphate $\left(\mathrm{PO}_{4}^{3^{-}}\right)$ & BDL & BDL & BDL & BDL \\
\hline Fluoride $\left(\mathrm{F}^{-}\right)$ & $0.25-0.74$ & $0.4-0.7$ & $0.4-0.9$ & $0.3-0.9$ \\
\hline
\end{tabular}


RASĀYAN J. Chem.

Vol. 11 | No. 2 |537 - 543 | April - June | 2018

\begin{tabular}{c|c|c|c|c} 
Nitrate $\left(\mathrm{NO}_{3}{ }^{-}\right)$ & $32.25-38.28$ & $39.32-42.76$ & $40.14-43.87$ & $35.21-44.29$ \\
\hline Sodium $(\mathrm{Na})$ & $67-74$ & $35-59$ & $44-55$ & $54-67$ \\
\hline Potassium(K) & $8.19-8.89$ & $7.38-7.98$ & $9.12-9.74$ & $9.29-9.58$ \\
\hline Calcium & $45-50$ & $45-50$ & $43-52$ & $45-50$ \\
\hline Magnesium & $21-28$ & $18-19$ & $17-23$ & $18-25$ \\
\hline Iron(Fe) & $0.11-0.19$ & $0.13-0.23$ & $0.16-0.29$ & $0.16-0.29$ \\
\hline Zinc $(\mathrm{Zn})$ & BDL & BDL & BDL & BDL \\
\hline Manganese(Mn) & BDL & BDL & BDL & BDL \\
\hline Lead $(\mathrm{Pb})$ & BDL & BDL & BDL & BDL \\
\hline
\end{tabular}

\section{Chemical Oxygen Demand}

The minimum value of COD was calculated on TG8 and TG7 $(1.0 \mathrm{mg} / \mathrm{L})$ in the month of October 2014, July'2015, October 2015 and September 2015 and maximum value of COD was calculated on TG1, TG5 and TG6 $(1.8 \mathrm{mg} / \mathrm{L})$ in the month of October2014, while standard value of BIS and WHO is 10.0 and $10.0 \mathrm{mg} / \mathrm{L}$ respectively.

\section{Chloride}

The minimum value of chloride was recorded on TG5, TG6, TG7 and TG8 (140.66 mg/L) in the month of October 2014 and maximum value of chloride was recorded on TG1 $(175.25 \mathrm{mg} / \mathrm{L})$ in the month of October 2014, while standard value of BIS and WHO is 200-1000 and 200-1000 mg/L respectively.

\section{Sulfate}

The minimum value of sulphate was noted on TG4 (104.00 mg/L) in the month of September 2014 and maximum value of sulphate was noted on TG2 $(285.00 \mathrm{mg} / \mathrm{L})$ in the month of July and August2014, July and August2015, while the standard value of BIS and WHO is 200-400 and 200-600 respectively.

\section{Phosphate}

In all the sampling station the observed value of $\mathrm{PO}_{4}{ }^{2-}$ was below detection limit (BDL), while the standard value of BIS and $\mathrm{WHO}$ is 0.1 and $0.1 \mathrm{mg} / \mathrm{L}$ respectively.

\section{Fluoride}

The minimum value of fluoride was noted on TG5 $(0.25 \mathrm{mg} / \mathrm{L})$ in the month of October 2014 and the maximum value of fluoride was noted on TG1 $(0.93 \mathrm{mg} / \mathrm{L})$ in the month of August 2015 , while the standard value of BIS and WHO is $1-1.2$ and $1-1.5 \mathrm{mg} / \mathrm{L}$ respectively.

\section{Nitrate}

The minimum value of nitrate was recorded on TG1 $(25.45 \mathrm{mg} / \mathrm{L})$ in the month of September-October 2014 and maximum value of fluoride was recorded on TG2 (44.76 mg/L) in the month of August 2015, while the standard value of BIS and WHO is 45 and $50 \mathrm{mg} / \mathrm{L}$ respectively.

\section{Sodium}

The minimum value of sodium was examined on TG2 $(32.00 \mathrm{mg} / \mathrm{L})$ in the month of August 2015 and maximum value of sodium was examined on TG1 and TG5 $(74.00 \mathrm{mg} / \mathrm{L})$ in the month of July 2014 , while the standard value of BIS and WHO is 75-200 and $200 \mathrm{mg} / \mathrm{L}$ respectively.

\section{Potassium}

The minimum value of K was noted on TG1 (7.22 mg/L) in the month of August 2014 and August 2015 and the maximum value of $\mathrm{K}$ was noted on TG4 $(9.74 \mathrm{mg} / \mathrm{L})$ in the month of August2014. While the standard value of BIS and WHO is 100 and $25 \mathrm{mg} / \mathrm{L}$ respectively. 


\section{Calcium}

The minimum value of Ca was calculated on TG7 $(43.00 \mathrm{mg} / \mathrm{L})$ in the month of September 2014 and the maximum value of Ca was calculated on TG1 $(65.00 \mathrm{mg} / \mathrm{L})$ in the month of October 2015 , while the standard value of BIS and WHO is 75-200 and 25-200 mg/L respectively.

\section{Magnesium}

The minimum value of $\mathrm{Mg}$ was noted on TG1 (11.00 mg/L) in the month of October 2014 and maximum value of Mg was noted on TG4 and TG5 $(28.00 \mathrm{mg} / \mathrm{L})$ in the month of August2015, while the standard value of BIS and WHO is $30-100$ and $30-150 \mathrm{mg} / \mathrm{L}$ respectively.

\section{Iron}

The minimum value of Fe was calculated on TG1and TG5 $(0.11 \mathrm{mg} / \mathrm{L})$ in the month of July 2014 and July 2015 and the maximum value of Fe was calculated on TG7 and TG8 $(0.29 \mathrm{mg} / \mathrm{L})$ in the month of October 2014 and July 2014. While the standard value of BIS and WHO is $0.3-1.0$ and $0.3-1.0 \mathrm{mg} / \mathrm{L}$ respectively.

\section{Zinc}

In all the sampling station the observed value of $\mathrm{Zn}$ was below detection limit (BDL), while the standard value of BIS and WHO is 5.0-15 and $3 \mathrm{mg} / \mathrm{L}$ respectively.

\section{Manganese}

In all the sampling station the observed value of Mn was below detection limit (BDL), while the standard value of BIS and WHO is $0.1-0.3$ and $0.5 \mathrm{mg} / \mathrm{L}$ respectively.

\section{Lead}

In all the sampling station the observed value of $\mathrm{Pb}$ was below detection limit (BDL), while the standard value of BIS is $0.05 \mathrm{mg} / \mathrm{L}$.

\section{CONCLUSION}

Water is an important asset of ecology and it is the essential commodity for human consumption without it no life can exist. Scarcity and lack of pure drinking water in the ecology will create disorder leading to ecological imbalance. Pure drinking water resources are deteriorating due to deforestation, mining and industrialization. The systematic exploration has been taken into consideration to assess the different water quality parameters of Takhatapur area, C.G. India. The physicochemical parameter with some heavy metals Iron, Zinc, Manganese and Lead, their obtained value is compared with the national and international water quality regulatory authority (BIS and WHO).

The experimental value of dissolved Oxygen, was found in TG4 $(6.5 \mathrm{mg} / \mathrm{L})$ in the month of Septemberand October2015 of monsoon season which is above the maximum limit of BIS and WHO (5.0 and 5.0-6.0 $\mathrm{mg} / \mathrm{L}$ ). And in all the sampling station the observed value of temperature, $\mathrm{pH}$, Electrical Conductivity, Turbidity, Total Dissolved Solids, Total Solids, Total Suspended Solids, Total Hardness, Alkalinity, Biological Oxygen Demand, Chemical Oxygen Demand, Chloride, Sulphate, Fluoride, Nitrate, Sodium, Potassium, Calcium, Magnesium, Iron $(\mathrm{Fe})$ are under the desirable limit of BIS and WHO of monsoon season. And in all the sampling station the observed value of Phosphate, Zinc, Manganese, Lead are below the detection limit (BDL) of the monsoon seasons.

\section{ACKNOWLEDGMENT}

Some faculty members of the institute have been very kind enough to extend their help at various phases of this research, whenever I approached them, and I do hereby acknowledge all of them. I was very much privileged to learn from Dr. Manish Upadhyay, Head Department of Chemistry, Dr. C.V. Raman University, Krgi Road, Kota, Bilaspur, (Chhattisgarh) India.

\section{REFERENCES}

1. N.C. Das, International Research Journal of Environment Sciences, 2(11), 96(2013). 
RASĀYAN J. Chem.

Vol. 11 | No. 2 |537 - 543 | April - June | 2018

2. F. T. Patel, G. M. Malik, A. S. Patel, International Journal of Scientific Engineering and Research, 5(8), 1(2017).

3. Hait Milan, Chouhan Naresh Ram, Nag Kavita, Journal of Scientific Letters, 1(2), 63(2016).

4. S. Karthick, R.M. Jenifer Priyanka, K. Suganthapriya, M. A. Sudhakar, International Journal of Engineering Science and Innovative Technology, 4(2): 173-177 (2015).

5. Bjorn Lomborg, The Skeptial Environmentalist, Cambridge University Press, 22 (1998).

6. R. Sudha., International Research Journal of Natural and Applied Sciences, 3(2), 46(2016).

7. V.H. Raval and G.M. Malik, Ultra Chemistry, 7(2), 173(2011).

8. M. Upadhayay, Ph.D. Thesis, Department of Chemistry, Guru Ghasidas Vishwavidyalaya, Bilaspur, Chhattisgarh, India(2002).

9. M. M. Vaishanv S. Dewangan, Rasayan J. Chem., 3(4), 710(2010).

10. H. Kaur (2015) Environmental Chemistry, Pragati Prakashan, New Delhi

[RJC-2089/2018] 